\title{
Hypsiboas caingua Carrizo, 1990 (Anura: Hylidae): First record for the State of Santa Catarina, Brazil
}

\author{
José Carlos Rocha Júnior ${ }^{1^{*}}$ and Luís Olímpio Menta Giasson ${ }^{2}$ \\ 1 ECOAMA Consultoria e Assessoria Ambiental. Rua Silvano Cândido da Silva Sênior, 140, Sala 03, Ponta Aguda. CEP 89050-280. Blumenau, SC, \\ Brazil. \\ 2 Universidade Regional de Blumenau, Centro de Ciências Exatas e Naturais, Departamento de Ciências Naturais, Laboratório de Biologia Animal. \\ Rua Antônio da Veiga, 140, Victor Konder. CEP 98012-000. Blumenau, SC, Brazil. \\ * Corresponding author. E-mail: jcrochabio@gmail.com.br
}

\begin{abstract}
In Brazil, Hypsiboas caingua has been previously registered for the States of São Paulo, Mato Grosso do Sul, and Rio Grande do Sul. Herein, we report individuals of $H$. caingua from the municipality of Passos Maia, in the State of Santa Catarina, which correspond to a new Brazilian state record and also a filing gap of distribution for this species.
\end{abstract}

DOI: $10.15560 / 10.3 .583$

Hypsiboas caingua was described by Carrizo (1990) based on individuals from northeastern Argentina as Hyla caingua, and subsequently species was found in Paraguay, and Brazil (Langone 1993; Aquino et al. 1996; Garcia and Vinciprova 1998; Brusquetti et al. 2006). In Brazil, species has been recorded for the states of Rio Grande do Sul (Garcia and Vinciprova 1998), São Paulo (Melo et al. 2007; Condez et al. 2009; Brassaloti et al. 2010; Araujo and AlmeidaSantos 2011), and Mato Grosso do Sul (Souza-Filho and Lima 2012). On 19 August 2012, between 20:00 and 21:00, during fieldwork in the municipality of Passos Maia, State of Santa Catarina, we recorded the presence of five males of $H$. caingua (Figure 1). Voucher specimens were collected and deposited at the scientific zoological collection of the laboratory of animal biology at the Universidade Regional de Blumenau (FURB 22154 and 22155), in the municipality of Blumenau, Santa Catarina (Collection Permits - FATMA AuA $N^{\circ}$ 020/2012). The specimens were identified based on the original description [Carrizo, 1990 (MACN 33194)] and by comparison with specimens deposited at herpetological collection of "Museo Argentino de Ciencias Naturales Bernardino Rivadavia" (MACN 43619 and 43629), municipality of Buenos Aires, Argentine. All specimens observed were males calling along two sites of the Chapecó River (Figure 2). The first site $\left(26^{\circ} 42^{\prime} 27.31^{\prime \prime}\right.$ $\mathrm{S}, 51^{\circ} 53^{\prime} 27.08^{\prime \prime} \mathrm{W}, 1.053 \mathrm{~m}$ ) correspond to a small area of backwater on the bank of the river, where the males were on shrubs and macrophytes. The second site $\left(26^{\circ} 42^{\prime} 47.31^{\prime \prime}\right.$ $\mathrm{S}, 51^{\circ} 54^{\prime} 22.67^{\prime \prime} \mathrm{W}, 1.027 \mathrm{~m}$ ) is in an area of backwater in the reservoir from Passos Maia Hydroelectric were only one male was registered calling from a shrub.

Reproductively active individuals of Hypsiboas caingua have been registered in gallery forests and small streams (Araújo and Almeida-Santos 2011) in ponds and permanent puddles (Brassaloti et al. 2010). The species is uncommon in standing water, but in areas with flowing water it can be found in backwater near the margin vegetation (Carrizo 1990; Brassaloti et al. 2010).
Reproductive environments for this species are usually associated with forest clearings or along borders of forests (Carrizo 1990; Brassaloti et al. 2010). Vocalizing males are found on soil or in vegetation, such as grass near water or up to 1 meter high in shrubby vegetation (Carrizo 1990; Brassaloti et al. 2010; Melo et al. 2007). It is also a species

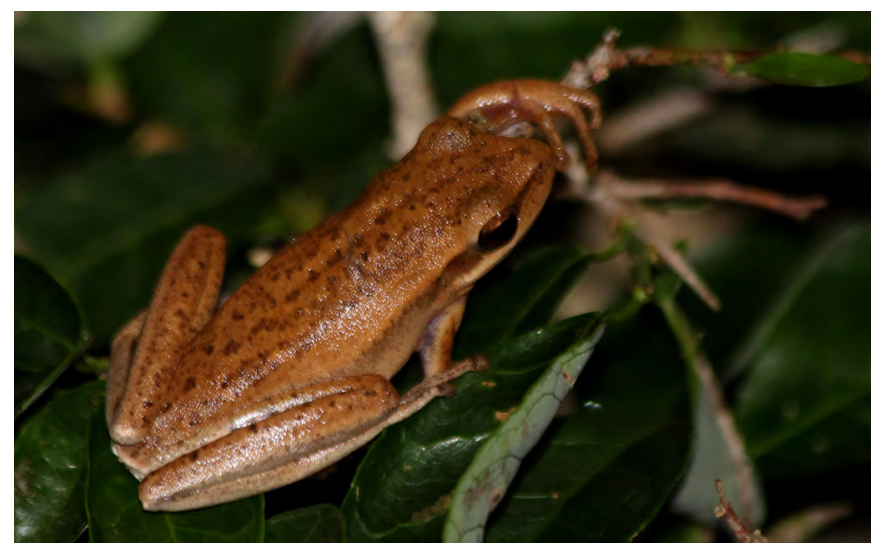

FIGURE 1. Hypsiboas caingua male (FURB 22154) from the municipality of Passos Maia, State of Santa Catarina, Brazil.

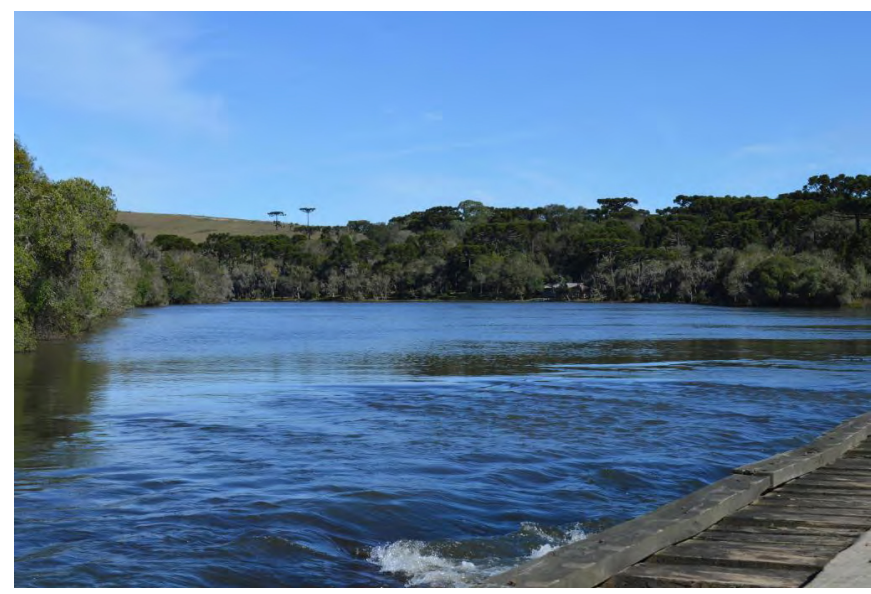

FigurE 2. The Chapecó River, the location of the record of Hypsiboas caingua, in the municipality of Passos Maia, State of Santa Catarina, Brazil. 


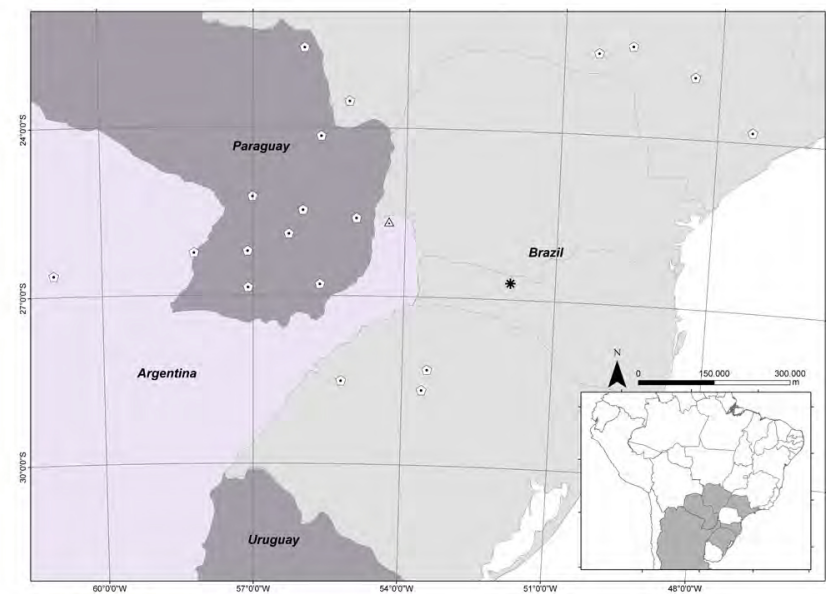

FIGURE 3. Location of new record of Hypsiboas caingua (black asterisk), in the municipality of Passos Maia, Santa Catarina. Known distribution of the species in Brazil (based on Garcia and Vinciprova 1998; Melo et al. 2007; Condez et al. 2009; Brassaloti et al. 2010; Araujo and AlmeidaSantos 2011; Souza-Filho and Lima 2012), Paraguay (based on Langone 1993; Aquino et al. 1996; Brusquetti et al. 2006) (white pentagons) and holotype (white triangle) in Argentina (based on Carrizo, 1990).

apparently adapted to lower temperatures (Melo et al. 2007). In three previous fieldworks at the same area, in the months of March, October and December 2010, none individuals were observed, suggesting that species may have low local abundance and reproductive activity is associated to lower temperatures. However, this species is known to be reproductively active throughout the year but there are fewer active males during colder periods (Carrizo 1990; Brassaloti et al. 2010).

This is the first record of $H$. caingua for Santa Catarina and also a filling gap of distribution for species in Brazil, extending its distribution ca. $220 \mathrm{~km}$ northwards from municipality of Panambi, Rio Grande do Sul (Garcia and Vinciprova 1998) and ca. $482 \mathrm{~km}$ southwards from municipality of Assis, São Paulo (Araújo and AlmeidaSantos 2011) (Figure 3). The new record, comprising a distance by ca. $267 \mathrm{~km}$ of the holotype (Carrizo 1990). Thus, in Brazil, current knowledge on species distribution comprises the states of Rio Grande do Sul, Santa Catarina, São Paulo and Mato Grosso do Sul. This record shows that the species has isolated populations in their distribution. Populations probably occur in the State of Paraná, where the species has not been recorded.
ACKNOWLEDGMENTS: The authors thank ECOAMA Consultoria e Assessoria Ambiental for the materials and logistics of fieldwork and Leandro Blunk for making the map. Thanks Julián Faivovich, the curator, and Santiago Javier Nenda, technical of the herpetological collection of Museo Argentino de Ciencias Naturales Bernardino Rivadavia. The authors also thank Nathan Smith for reviewing the English.

\section{LITERATURE CITED}

Aquino, A.L., N.J. Scott and M. Motte. 1996. Lista de anfíbios y reptiles del Museo de Historia Natural del Paraguay (Marzo, 1980 - Septiembre, 1995); pp. 331-400, in: O.R. Romero (ed.). Coleccion de Flora y Fauna del Museo Nacional de Historia Natural del Paraguay. Asuncion: Museo Nacional de Historia Natural del Paraguay.

Araujo, C.O. and S.M. Almeida-Santos. 2011. Herpetofauna de um remanescente de cerrado no estado de São Paulo, sudeste do Brasil. Biota Neotropica 11(3): 1-16 (doi: 10.1590/S167606032011000300003).

Brassaloti, R.A., D.C. Rossa-Feres and J. Bertoluci. 2010. Anurofauna da Floresta Estacional Semidecidual da Estação Ecológica dos Caetetus, Sudeste do Brasil. Biota Neotropica 10(1): 275-292 (doi: 10.1590/ S1676-06032010000100024).

Brusquetti, F. and E.O. Lavilla. 2006. Lista comentada de los anfibios de Paraguay. Cuadernos de Herpetología 20(2): 3-79 (http://www. aha.org.ar/es/cuadherpetol/lista-comentada-de-los-anfibios-deparaguay.pdf).

Carrizo, G. 1990. Sobre los hilidos de Misiones, Argentina, con la descripción de una nueva especie, Hyla caingua n. sp. (Anura, Hylidae). Cuadernos de Herpetología 5(6): 32-39 (http://www.aha. org.ar/es/cuadherpetol/sobre-los-hilidos-de-misiones-argentinacon-la-descripcion-de-una-nueva-especie-hyla-caingua-n-sp-anurahylidae.pdf)

Condez, T.H., R.J. Sawaya and M. Dixo. 2009. Herpetofauna dos remanescentes de Mata Atlântica da região de Tapiraí e Piedade, SP, sudeste do Brasil. Biota Neotropica 9(1): 157-185 (doi: 10.1590/ S1676-06032009000100018).

Garcia, P.C.A. and G. Vinciprova. 1998. Range extensions of some anuran species for Santa Catarina and Rio Grande do Sul states, Brazil. Herpetological Review 29(2): 117-118.

Langone, J.A. 1993. Ampliación de la distribución geográfica de Hyla caingua Carrizo, 1990 (Amphibia, Anura, Hylidae). Boletín de la Asociación Herpetológica Argentina 9: 8.

Melo, G.V., D.C. Rossa-Feres and J. Jim. 2007. Variação temporal no sítio de vocalização em uma comunidade de anuros de Botucatu, Estado de São Paulo, Brasil. Biota Neotropica 7(2): 93-102 (doi: 10.1590/ S1676-06032007000200011).

Souza-Filho, G.A., and A.M.X. de Lima. 2012. Hypsiboas caingua (Carrizo, 1990) (Amphibia: Anura: Hylidae): Geographic distribution with a new state record in Brazil. Check List 8(4): 800-801 (http://www. checklist.org.br/getpdf?NGD004-12).

RECEIVED: August 2013

ACCEPTED: February 2014

PUBLISHED ONLINE: July 2014

EDITORIAL RESPONSIBILITY: Raul Maneyro 